\title{
IDENTIFIKASI BAHAYA DENGAN METODE PRELIMINARY HAZARD ANALYSIS (PHA) PADA WORKSHOP POLITEKNIK SINAR MAS BERAU COAL KABUPATEN BERAU, KALIMANTAN TIMUR
}

\author{
Fahriza Fawwas Asrory ${ }^{1}$, Anthonius Dhinar Hasto Wisnugroho ${ }^{2}$
}

${ }^{1}$ Teknologi Rekayasa Logistik /Politeknik Sinar Mas Berau Coal / riza.asrory@gmail.com

${ }^{2}$ Teknologi Rekayasa Logistik/Politeknik Sinar Mas Berau Coal / adhinar1393@gmail.com

\begin{abstract}
Occupational Safety and Health (K3) is a top priority for a company or an educational institution to reduce the possibility of the emergence of a risk, both natural risk and human life that has the potential to cause unsafe conditions and unsafe actions. Sinar Mas Berau Coal Polytechnic as one of the universities in Berau Regency has a workshop or workshop to support academic activities, especially the Mechanical Maintenance Study Program which of course in every activity in the workshop has the potential to cause potential dangers and risks that can cause losses. The method used in this study is Preliminary Hazard Analysis (PHA) where this method is used to identify potential hazards that can occur at the Sinar Mas Berau Coal Polytechnic Workshop. The results of this study are that there are 9 activities in which there are 31 potential hazards and risks with an average risk assessment result of 60.98 which is included in Priority 3 status so that supervision is needed during activities carried out in the workshop area.
\end{abstract}

Keywords : K3, work safety, occupational health, PHA, workshop

\begin{abstract}
ABSTRAK
Keselamatan dan Kesehatan Kerja (K3) menjadi prioritas utama bagi suatu perusahaan ataupun suatu instansi pendidikan untuk mereduksi kemungkinan munculnya sebuah risiko baik risiko yang dari alam (natural Risk) maupun dari kehidupan manusia yang berpotensi menimbulkan kondisi tidak aman dan tindakan tidak aman. Politeknik Sinar Mas Berau Coal sebagai salah salah satu perguruan tinggi di Kabuaten Berau memiliki workshop atau bengkel dalam menunjang aktivitas akademik khususnya Prodi Perawatan Mesin yang tentu dalam setiap kegiatan yang ada di workshop tersebut berpotensi menimbulkan bahaya dan risiko potensial yang dapat menyebabkan kerugian. Metode yang digunakan dalam penelitian ini adalah Preliminary Hazard Analysis (PHA) dimana metode ini digunakan untuk mengidentifikasi potensi bahaya yang dapat terjadi di Workshop Politeknik Sinar Mas Berau Coal. Hasil dari penelitian ini adalah terdapat 9 aktivitas yang didalamnya ada 31 bahaya dan risiko potensial dengan hasil rata-rata penilaian risiko adalah sebesar 60,98 masuk dalam status Priority 3 sehingga diperlukan pengawasan selama aktivitas yang dilakukan di area workshop.
\end{abstract}

Kata Kunci : K3, keselamatan kerja, kesehatan kerja, PHA, Workshop

\section{PENDAHULUAN}

Keselamatan merupakan faktor penting yang harus dijaga agar mampu mengantisipasi kemungkinan terjadinya kecelakaan kerja yang dapat merugikan suatu perusahaan atau suatu instansi baik secara langsung maupun tidak langsung. Keselamatan kerja memiliki tujuan untuk melindungi pekerja atas keselamatan, terpeliharanya sumber-sumber produksi dengan baik sehingga dapat digunakan secara efisien dan aman serta meningkatkan produksi, dan meningkatkan kesejahteraan hidup pekerja. Hingga saat ini, keselamatan menjadi prioritas utama bagi suatu perusahaan ataupun suatu instansi termasuk pada dunia pendidikan. Kecelakaan kerja sering terjadi akibat tindakan ceroboh, kondisi yang tidak aman, serta tindakan yang tidak aman. Menurut Navenata dan Masrofah (2020) setiap perusahaan bahkan hampir semua perusahaan yang menerapkan sistem keselamatan kerja menetapkan bahwa indikator keberhasilan adalah tidak terjadinya kecelakaan kerja atau kehilangan waktu kerja karena adanya kecelakaan. Nol kecelakaan (Zero Accident) atau nol cedera waktu yang hilang (Zero Lost Time Injury) merupakan 
suatu target yang hasilnya merupakan suatu proses pengendalian bahaya atau sumber bahaya sehingga tidak terjadi kecelakaan.

Politeknik Sinar Mas Berau Coal merupakan salah satu perguruan tinggi di Kabupaten Kalimantan Timur yang memiliki workshop atau bengkel untuk menunjang aktivitas akademik khususnya Prodi Perawatan Mesin. Dalam aktivitas dan kondisi dari workshop tersebut tentu terdapat bahaya dan risiko potensial yang dapat menyebabkan kerugian. Adanya kemungkinan timbulnya kerugian besar, diperlukan suatu upaya identifikasi yang salah satunya adalah dengan menerapkan metode Preliminary Hazard Analysis (PHA) untuk mengidentifikasi bahaya yang kemungkinan dapat terjadi (Prabowo dkk., 2017).

Langkah selanjutnya adalah mengidentifikasi pengendalian atau mitigasi yang dibutuhkan dan kemudian melakukan tindak lanjut. Setelah dilakukan langkah-langkah tersebut, diharapkan dapat memperkecil kemungkinan terjadinya risiko dari bahaya yang ditimbulkan. Menurut Ericson (2005), meskipun data atau informasi yang didapat minim atau terbatas, informasi mengenai potensi-potensi bahaya keselamatan yang belum pernah terjadi atau dikenal sebelumnya dapat diidentifikasi lebih awal dan output dari PHA ini menghasilkan identifikasi bahaya, risiko kecelakaan yang terjadi, faktor penyebab 2 dan efek risiko kecelakaan serta pengendalian risiko tersebut sehingga bahaya keselamatan yang ada dapat ditanggulangi dengan sedini mungkin dengan pengendalian yang tepat.

\section{STUDI PUSTAKA}

Bahaya Keselamatan Kerja (Safety Hazard) merupakan bahaya yang berdampak pada timbulnya kecelakaan kerja yang dapat menyebabkan luka (injury), cacat hingga kematian serta kerusakan property, sedangkan bahaya kesehatan kerja (Health Hazard) merupakan bahaya yang mempunyai dampak terhadap kesehatan manusia dan penyakit akibat kerja dan bersifat kronis.

Preliminary Hazard Analysis (PHA) merupakan analisis semikuantitatif yang digunakan untuk mengidentifikasi semua potensi bahaya dan peristiwa kecelakaan yang mungkin menyebabkan kecelakaan dan mengidentifikasi pengendalian bahaya yang diperlukan dan tindakan tindak lanjut atau juga biasa disebut untuk melakukan perangkingan risiko dan memeriksa (identifikasi) bahaya (Rausand, 2005). Analisis PHA adalah metode analisis keselamatan kerja untuk mengidentifikasi bahaya, faktor-faktor penyebab yang terkait, efek, tingkat risiko, dan tindakan mitigasi desain ketika informasi yang detail tidak tersedia dan terbatas, sehingga maksud PHA agar sedini mungkin bahaya dapat diidentifikasi untuk program pembangunan (Ericson, 2005).

Penggunaan metode PHA berdasarkan pertimbangan kemudahan prosedur identifikasi, jenis proses pekerjaan yang diteliti, dan bertujuan untuk mengidentifikasi secara dini potensi bahaya keselamatan yang berpotensi timbul atau potensi bahaya yang sebelumnya belum dikenal terjadi pada pengoperasian peralatan maupun setiap cara kerja dalam suatu proses, aktivitas, dan kegiatan (Ericson, 2005). Selanjutnya dilakukan analisis risiko, tingkatan risiko dengan teknik kualitatif berdasarkan teori Marvin Rausand untuk mengetahui estimasi frekuensi dan konsekuensi risiko dan melakukan evaluasi risiko menggunakan konsep ALARP (As Low as Reasonably Practicable).

Penelitian ini menggunakan metode PHA dimana penelitian akan dilakukan di Workshop Politeknik Sinar Mas Berau Coal dengan mengamati setiap kegiatan praktikum yang dilakukan di workshop serta area workshop. Pengamatan dilakukan untuk mengidentifikasi potensi bahaya sehingga dapat dilakukan tindakan pencegahan atau mitigasi untuk mengurangi dampak risiko yang mungkin dapat terjadi.

\section{HASIL, ANALISA DATA DAN PEMBAHASAN}

Dalam penilaian risiko pada metode PHA, digunakan 3 parameter yaitu probability, consequences, dan exposure. 1. Probability Probability adalah seberapa besar peluang atau 
kemungkinan dari suatu kejadian bahaya dan risiko potensial yang dapat terjadi maupun sudah terjadi. 2. Consequences Consequences adalah seberapa besar dampak dari suatu kejadian bahaya dan risiko potensial yang dapat terjadi maupun sudah terjadi. 3. Exposure Exposure adalah seberapa sering pajanan dari suatu kejadian bahaya dan risiko potensial terhadap pekerja atau manusia. Penilaian risiko pada metode PHA menggunakan rumus yaitu mengalikan $\mathrm{C}$ x $\mathrm{P}$ x E dimana $\mathrm{C}=$ Consequences $\mathrm{P}=$ Probability $\mathrm{E}=$ Exposure. Hasil identifikasi bahaya dan risiko potensial dengan menggunakan metode PHA dapat diperoleh data aktivitas dan potensi bahaya dan risiko dengan 3 parameter yang digunakan yaitu probability, consequences, dan exposure seperti yang ditunjukkan pada Tabel 1 .

Tabel 1. Identifikasi Bahaya dan Risiko Potensial Menggunakan Metode PHA pada Workoshop Politeknik Sinar Mas Berau Coal

\begin{tabular}{|c|c|c|c|c|c|c|c|}
\hline No. & $\begin{array}{l}\text { Kegiatan di } \\
\text { Workshop }\end{array}$ & Bahaya & Risiko & $\begin{array}{c}\text { Prob } \\
\text { abili } \\
\text { ty }\end{array}$ & $\begin{array}{l}\text { Con } \\
\text { sequ } \\
\text { ence } \\
\text { s }\end{array}$ & $\begin{array}{c}\text { Exp } \\
\text { osur } \\
e\end{array}$ & $\begin{array}{c}\text { Tindakan } \\
\text { Pencegahan }\end{array}$ \\
\hline 1. & $\begin{array}{l}\text { Pengoperasian } \\
\text { teaching aid } \\
\text { "gentset" }\end{array}$ & $\begin{array}{l}\text { 1. Asap } \\
\text { 2. Bising } \\
\text { 3. Mesin panas } \\
\text { 4. Aliran listrik } \\
\text { mesin genset } \\
\text { 5. Area jalan di } \\
\text { dalam workshop } \\
\text { sempit. }\end{array}$ & $\begin{array}{l}\text { 1. Terhirup asap } \\
\text { pembakaran. } \\
\text { 2. Pendengaran } \\
\text { berkurang akibat } \\
\text { bising. } \\
\text { 3. Tangan melepuh } \\
\text { akibat terkena } \\
\text { mesin panas. } \\
\text { 4. Tersengat listrik } \\
\text { saat mengoperasik } \\
\text { an gentset. } \\
\text { 5. Tersandung saat } \\
\text { pengecekanmesin. }\end{array}$ & 3 & 25 & 2 & 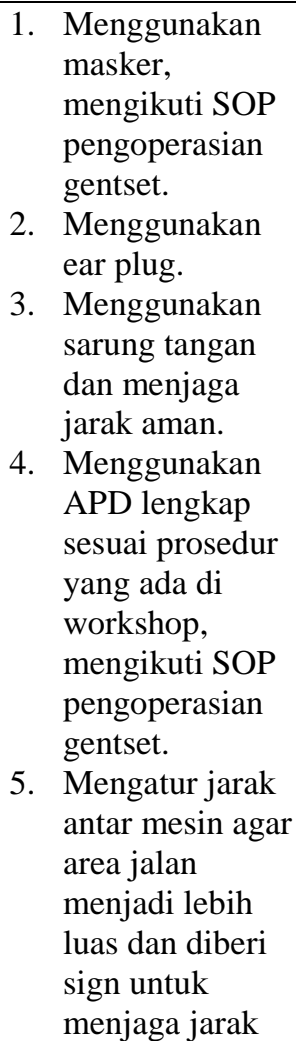 \\
\hline 2. & $\begin{array}{l}\text { Penggantian } \\
\text { sparepart } \\
\text { mesin }\end{array}$ & $\begin{array}{l}\text { 1. Mesin berat. } \\
\text { 2. Sparepart mesin. } \\
\text { 3. Sparepart mesin. } \\
\text { 4. Tumpahan oli. }\end{array}$ & $\begin{array}{l}\text { 1. Terjepit mesin } \\
\text { berat. } \\
\text { 2. Tertimpa } \\
\text { sparepart mesin. } \\
\text { 3. Tersandung } \\
\text { sparepart mesin. } \\
\text { 4. Terpeleset akibat } \\
\text { tumpahan oli. }\end{array}$ & $\begin{array}{l}1 \\
1\end{array}$ & 5 & $\begin{array}{l}2 \\
2\end{array}$ & $\begin{array}{ll}\text { 1. } & \text { Menggunakan } \\
\text { APD lengkap } \\
\text { sesuai prosedur } \\
\text { yangada di } \\
\text { workshop. } \\
\text { 2. } \\
\text { Menggunakan } \\
\text { APD lengkap } \\
\text { sesuai prosedur } \\
\text { yangada di } \\
\text { workshop. } \\
\text { 3. Menjaga jarak } \\
\text { aman mesin. } \\
\text { 4. Menghilangkan } \\
\text { ceceran oli } \\
\text { dengan }\end{array}$ \\
\hline
\end{tabular}


Jurnal Inkofar * Volume 5 No. 1, Juli 2021 * E-ISSN: 2581-2920

Tersedia secara online di: http://www.politeknikmeta.ac.id/meta/ojs/

\begin{tabular}{|c|c|c|c|c|c|c|c|}
\hline & & & & & & & mengepel. \\
\hline 3. & $\begin{array}{l}\text { Pengoperasian } \\
\text { teaching aid } \\
\text { "electrical } \\
\text { body system" }\end{array}$ & Aliran listrik & Tersengat listrik & 1 & 25 & 2 & $\begin{array}{l}\text { Mengikuti SOP } \\
\text { pengoperasian } \\
\text { teaching aid } \\
\text { "electrical body } \\
\text { system", } \\
\text { menggunakanAPD } \\
\text { lengkap sesuai } \\
\text { dengan prosedur } \\
\text { yang ada di } \\
\text { workshop }\end{array}$ \\
\hline 4. & $\begin{array}{l}\text { Kegiatna } \\
\text { praktek } \\
\text { mahasiswa } \\
\text { "mengikir" }\end{array}$ & $\begin{array}{l}\text { 1. Alat kikir. } \\
\text { 2. Debu bekas } \\
\text { pengikiran. } \\
\text { 3. Debu bekas } \\
\text { pengikiran. } \\
\text { 4. Ragung. } \\
\text { 5. Sikat kawat } \\
\text { pembersih }\end{array}$ & 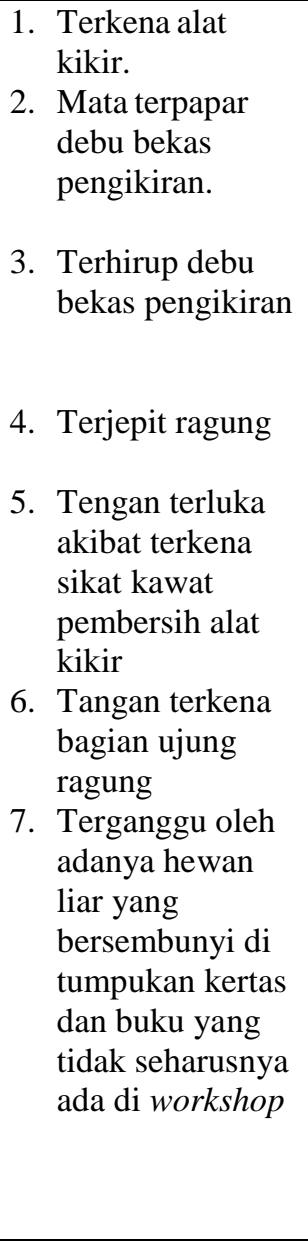 & 1 & 15 & 2 & $\begin{array}{l}\text { 1. Menggunakan } \\
\text { sarung tangan, } \\
\text { memastikan } \\
\text { kondisi badan fit } \\
\text { saat melakukan } \\
\text { praktik } \\
\text { 2. Menggunakan } \\
\text { kacamata. } \\
\text { 3. Menggunakan } \\
\text { masker. } \\
\text { 4. Mengikuti SOP } \\
\text { pengikiran, } \\
\text { memastikan } \\
\text { kondisi badan fit } \\
\text { saat praktik. } \\
\text { 5. Menggunakan } \\
\text { sarung tangan. } \\
\text { 6. Mengikuti SOP } \\
\text { pengikiran, } \\
\text { memastikan } \\
\text { kondisi badanfit } \\
\text { saat melakukan } \\
\text { praktik. } \\
\text { 7. Memindahkan } \\
\text { tumpukan } \\
\text { tersebut keluar } \\
\text { workshop atau } \\
\text { dimusnahkan, } \\
\text { menjaga } \\
\text { kebersihan } \\
\text { workshop. }\end{array}$ \\
\hline 5. & $\begin{array}{l}\text { Mencuci } \\
\text { tangan }\end{array}$ & $\begin{array}{l}\text { 1. Lantai licin } \\
\text { 2. Keran } \\
\text { konvensional }\end{array}$ & $\begin{array}{l}\text { 1. Terpeleset pada } \\
\text { saat menuju area } \\
\text { mencuci tangan. } \\
\text { 2. Penularan virus } \\
\text { akibat keran } \\
\text { konvensional }\end{array}$ & 10 & 2 & 6 & $\begin{array}{l}\text { 1. Menghilangkan } \\
\text { genangan air } \\
\text { dengan } \\
\text { mengepel dan } \\
\text { rutin } \\
\text { membersihkan } \\
\text { lantai. } \\
\text { 2. Menyediakan } \\
\text { sabun di area } \\
\text { mencuci tangan } \\
\text { dan } \\
\text { memodifikasi } \\
\text { keran yang } \\
\text { touchless. }\end{array}$ \\
\hline 6. & Menggunakan & 1. Alat kebersihan & $\begin{array}{l}\text { 1. Tersandung alat } \\
\text { kebersihan }\end{array}$ & 10 & 1 & 6 & $\begin{array}{l}\text { 1. Merapikan alat } \\
\text { kebersihan di }\end{array}$ \\
\hline
\end{tabular}


Jurnal Inkofar * Volume 5 No. 1, Juli 2021 * E-ISSN: 2581-2920

Tersedia secara online di: http://www.politeknikmeta.ac.id/meta/ojs/

\begin{tabular}{|c|c|c|c|c|c|c|c|}
\hline & WC & $\begin{array}{l}\text { 2. Area kumuh } \\
\text { sekitaran WC } \\
\text { 3. Lantai licin }\end{array}$ & $\begin{array}{ll}\text { 2. } & \text { Terkena } \\
\text { penyakit seperti } \\
\text { DBD akibat } \\
\text { gigitan nyamuk } \\
\text { di area kumuh } \\
\text { sekitaran WC }\end{array}$ & 10 & 25 & 1 & $\begin{array}{l}\text { sekitar WC } \\
\text { 2. Menjaga agar } \\
\text { area WC serta } \\
\text { area sekitaran } \\
\text { WC tetap bersih } \\
\text { dan tidak ada } \\
\text { genangan air } \\
\text { yang berpotensi } \\
\text { menjadi sarang } \\
\text { nyamuk } \\
\text { 3. Menghilangkan } \\
\text { genangan air } \\
\text { ataupun debu } \\
\text { yang menumpuk } \\
\text { di sekitaran area } \\
\text { WC }\end{array}$ \\
\hline 7. & $\begin{array}{l}\text { Pengambilan } \\
\text { spare part di } \\
\text { gudang } \\
\text { penyimpa nan } \\
\text { barang }\end{array}$ & $\begin{array}{l}\text { 1. Tumpukan } \\
\text { barang di rak. } \\
\text { 2. Rak. }\end{array}$ & $\begin{array}{l}\text { 1. Tertimpa barang. } \\
\text { 2. Tersandung rak. }\end{array}$ & $\begin{array}{c}3 \\
10\end{array}$ & $\begin{array}{l}5 \\
2\end{array}$ & $\begin{array}{l}3 \\
3\end{array}$ & $\begin{array}{l}\text { 1. Mengikuti SOP } \\
\text { pengambilan } \\
\text { barang di } \\
\text { gudang. } \\
\text { 2. Mengikuti SOP } \\
\text { pengambilan } \\
\text { barang di } \\
\text { gudang. }\end{array}$ \\
\hline 8. & $\begin{array}{l}\text { Pengoperasian } \\
\text { mesinbubut }\end{array}$ & $\begin{array}{l}\text { 1. Genangan air } \\
\text { di sekitaran } \\
\text { tempat mengisi } \\
\text { airpada mesin } \\
\text { bubut. } \\
\text { 2. Suara bising } \\
\text { mesin bubut. } \\
\text { 3. Mesin bubut } \\
\text { licin/kotor. }\end{array}$ & $\begin{array}{ll}\text { 1. } & \begin{array}{l}\text { Terpeleset } \\
\text { akibat } \\
\text { genangan air } \\
\text { di sekitaran } \\
\text { tempat } \\
\text { mengisi air } \\
\text { pada mesin } \\
\text { bubut. }\end{array} \\
\text { 2. } & \begin{array}{l}\text { Kurangnya } \\
\text { pendengaran } \\
\text { akibat bising. }\end{array} \\
\text { 3. } & \begin{array}{l}\text { Tangan terpeleset } \\
\text { saat } \\
\text { mengoperasikan } \\
\text { mesin bubut. }\end{array}\end{array}$ & 10 & 15 & 2 & $\begin{array}{l}\text { 1. } \begin{array}{l}\text { Membersihkan } \\
\text { genangan air } \\
\text { dengan pel. }\end{array} \\
\text { 2. Menggunakan } \\
\text { ear plug. } \\
\text { 3. } \\
\text { Membersihkan } \\
\text { mesin bubut } \\
\text { setelah } \\
\text { digunakan. }\end{array}$ \\
\hline 9. & $\begin{array}{l}\text { Melewati area } \\
\text { workshop } \\
\text { menuju area } \\
\text { praktik }\end{array}$ & $\begin{array}{l}\text { 1. Alat, mesin / } \\
\text { sparepart yang } \\
\text { diletakkan } \\
\text { tidak pada } \\
\text { tempatnya. } \\
\text { 2. Debu di area } \\
\text { workshop. } \\
\text { 3. Benda tinggi } \\
\text { seperti buritan } \\
\text { truk. } \\
\text { 4. Besi untuk } \\
\text { kegiatan } \\
\text { produksi } \\
\text { bushing } \\
\text { dalam posisi } \\
\text { tidak benar. }\end{array}$ & 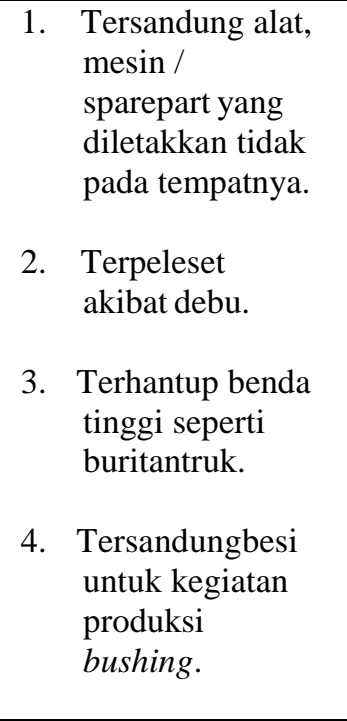 & 10 & 1 & 6 & 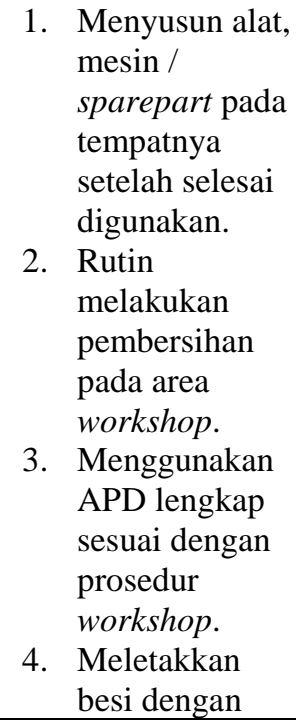 \\
\hline
\end{tabular}




\begin{tabular}{|l|l|l|l|l|l|l|}
\hline & & & & & posisi yang \\
benar agar \\
aman serta \\
memberikan \\
safety line di \\
sekitaran besi \\
agar terlihat.
\end{tabular}

Nilai tingkat keparahan dihasilkan dari hasil perkalian rata-rata dari tiga parameter terhadap seluruh bahaya dan risiko potensialdari aktivitas pada Workshop Politeknik Sinar Mas Berau Coal yang telah diidentifikasi berdasarkan metode PHA seperti yang ditunjukkan pada Tabel 2.

Tabel 2. Penilaian Risiko pada Aktivitas Workshop Politeknik Sinar Mas Berau Coal

\begin{tabular}{|l|c|c|}
\hline \multicolumn{1}{|c|}{ Kegiatan di Workshop } & $\begin{array}{c}\text { Total Rata-Rata } \\
(\mathbf{P ~ x ~ C ~ x ~ E ) ~}\end{array}$ & Status \\
\hline Pengoperasian mesin bubut & 73,3 & Substantial \\
\hline Pengoperasian teaching aid "gentset" & 70 & Priority 3 \\
\hline Penggantian sparepart mesin & 70 & Priority 3 \\
\hline Kegiatan praktek mahasiswa "mengikir" & 66 & Priority 3 \\
\hline Mencuci tangan & 66 & Priority 3 \\
\hline Menggunakan WC & 65 & Priority 3 \\
\hline $\begin{array}{l}\text { Pengambilan spare part di gudang } \\
\text { penyimpanan barang }\end{array}$ & 52,5 & Priority 3 \\
\hline $\begin{array}{l}\text { Pengoperasian teaching aid "electrical } \\
\text { body system" }\end{array}$ & 50 & Priority 3 \\
\hline $\begin{array}{l}\text { Melewati area workshop menuju area } \\
\text { praktik }\end{array}$ & 36 & Priority 3 \\
\hline Total Rata-Rata & 60,98 & \\
\hline
\end{tabular}

Dari hasil perhitungan total rata-rata identifikasi bahaya dan risiko potensial pada aktivitas Workshop Politeknik Sinar Mas Berau Coal maka didapatkan hasil rata-rata penilaian risiko secara keseluruhan terhadap kegiatan atau aktivitas di Workshop Politeknik Sinar Mas Berau Coal yang telah diidentifikasi adalah 60,98 dengan status Priority 3 sehingga tindakan yang harus dilakukan adalah membutuhkan pengawasan selamaaktivitas dilakukan di Workshop.

\section{KESIMPULAN}

Berdasarkan hasil pengamatan dan analisis pada area kerja (pratikum) Workshop Politeknik Sinar Mas Berau Coal dengan menggunakan metode Preliminary Hazard Analysis (PHA), maka diperoleh kesimpulan yaitu terdapat 9 jumlah aktivitas atau kegiatan yang berhasil diidentifikasi dan dari 9 aktivitas atau kegiatan tersebut, terdapat 31 jumlah bahaya dan risiko potensial yang dilakukan dengan menggunakan metode PHA. Hasil rata-rata penilaian risiko secara keseluruhan terhadap 9 jumlah aktivitas atau kegiatan adalah sebesar 60,98 dengan status Priority 3 sehingga tindakan yang harus dilakukan adalah membutuhkan pengawasan selama aktivitas dilakukan di Workshop.

\section{DAFTAR PUSTAKA}

Diklat Online Hira Ppsdm Geologi Mineral Dan Batubara Bandung, 22 April 2020.

Ericson C. A. (2005). Hazard Analysis Techniques for System Safety, Hoboken, John Wiley\&Sons, Inc, New Jersey; 24-29

Hadi, M. K. (2017). Analisis Quality Control Terhadap Risiko Kerusakan Produk (Study Pada PT. Semen Baturaja (Persero), Tbk Bandar Lampung. (Doctoral dissertation, UIN Raden Intan Lampung). 
Nevanata, R. C., dan Isma M. 2020. Penerapan Keselamatan Dan Kesehatan Kerja Di CV. Roti Golden Menggunakan Metode Preliminary Hazard Analysis. Seminar dan Konferensi Nasional IDEC 2020. 2579-6429.

Nuriawati, L. (2017). Evaluasi Penerapan Keselamatan Dan Kesehatan Kerja (K3) Berdasarkan Fault Tree Analysis (FTA), Failure Modes \& Effect Analysis (FMEA) dan Preliminary Hazard Analysis (PHA). FT Universitas Negeri Yogyakarta.

Prabowo, W. G., Wibowo A., Adhi S. (2017). Identifikasi Bahaya Dengan Metode Preliminary Hazard Analysis (PHA) Pada Bengkel/Lab Serta Pembuatan Sistem Informasi UPI K3 dan Pelaporan Kecelakaan (Studi Kasus di PPNS). Seminar Nasional K3 PPNS 2017 [Book 1]. 1(1) : $2581-1770$.

Putri, U. A., \& Ishak, R. F. (2019). Evaluasi Penerapan Keselamatan Dan Kesehatan Kerja (K3) Berdasarkan Sistem Manajemen (SMK3) Menggunakan Model Countenance Stake di PT. PINDAD (PERSERO), Bandung. (Doctoral dissertation, Universitas Pasundan).\&

Rausand, M. (2005). Preliminary Hazard Analysis. Norwegian: Norwegian University of Science and Technology.

\section{UCAPAN TERIMAKASIH}

a. Terimakasih kepada teman-teman Dosen dan instruktur Politeknik Sinar Mas Berau Coal

b. Terimakasih kepada Kepala Workshop Politeknik Sinar Mas Berau Coal selaku Narasumber dalam penelitian ini

c. Terimakasih kepada orang tua yang telah memberi dukungan bagi kami dalam penelitian ini.

d. Dan terimakasih kepada Seluruh Mahasiswa Perawatan Mesin yang membantu dalam proses penelitian ini.

\section{LAMPIRAN}

Makalah ini dilengkapi dengan lampiran yang berisi beberapa gambar kegiatan penelitian yang dapat dilihat pada gambar 1 dan gambar 2.

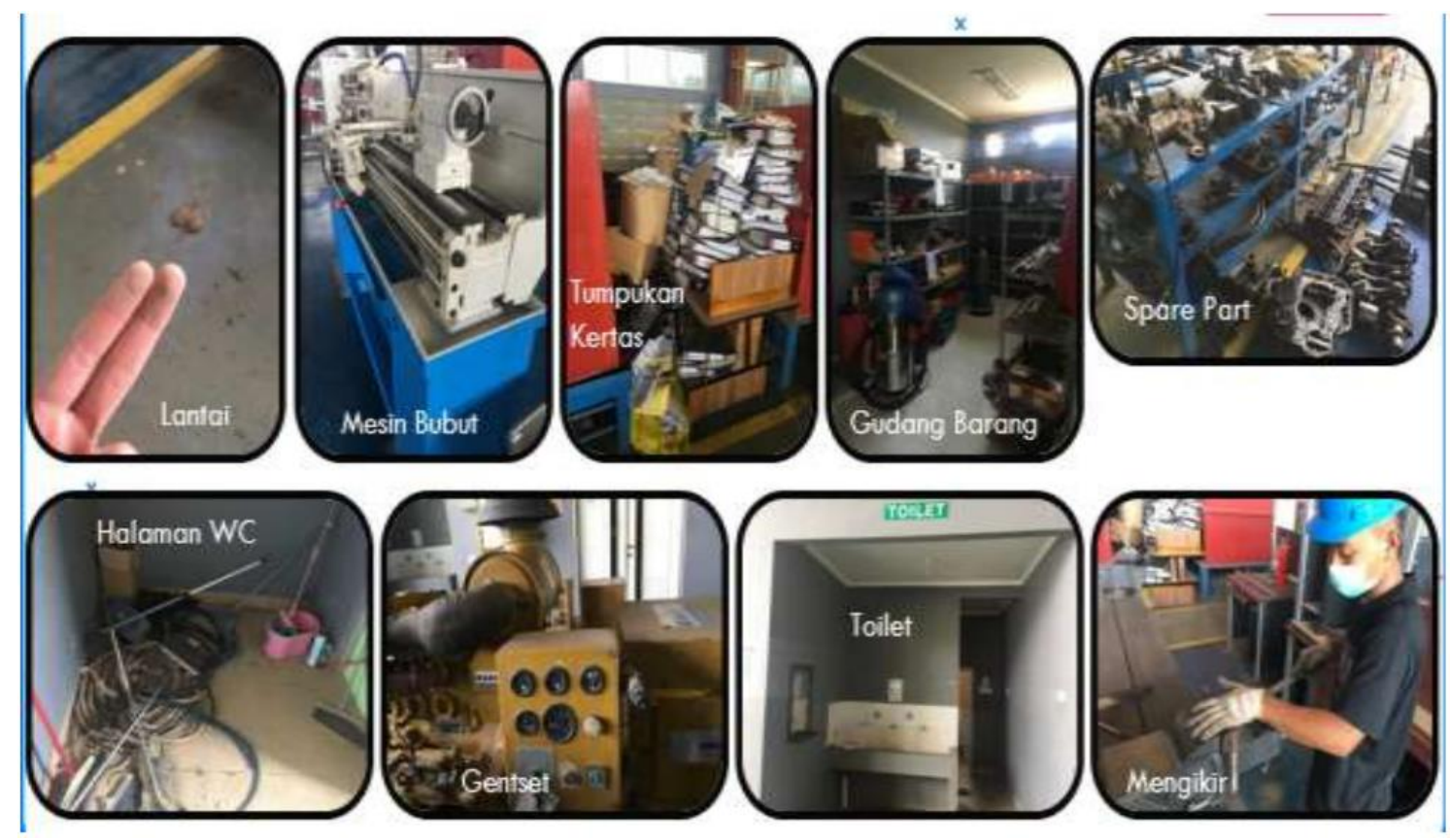

Gambar 1. Kondisi Workshop Politeknik Sinar Mas berau Coal 
Jurnal Inkofar * Volume 5 No. 1, Juli 2021 * E-ISSN: 2581-2920

Tersedia secara online di: http://www.politeknikmeta.ac.id/meta/ojs/

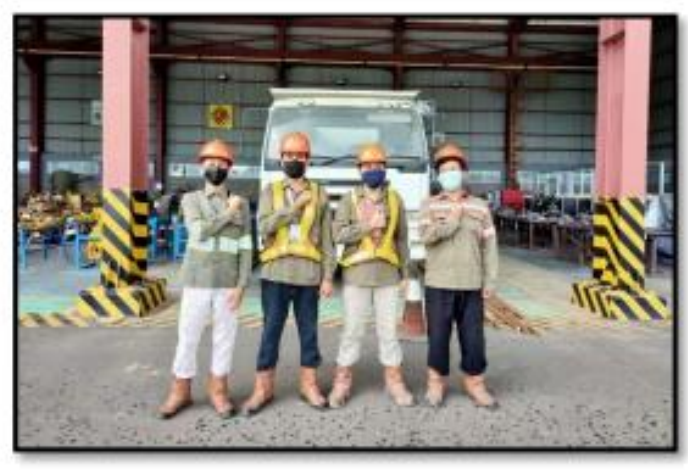

Gambar 2. Team PHA

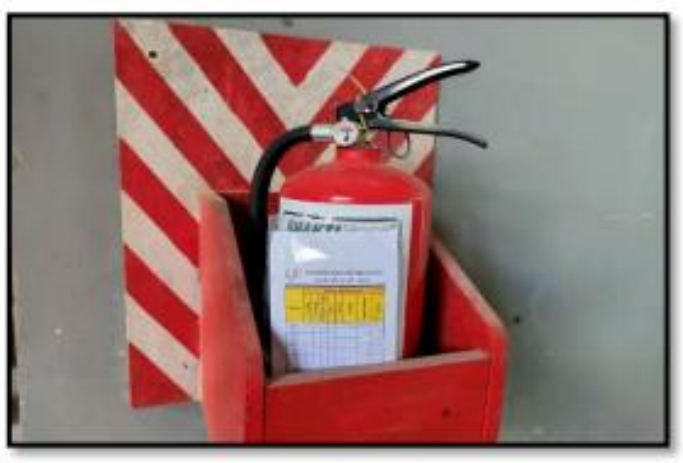

Gambar 4. APAR

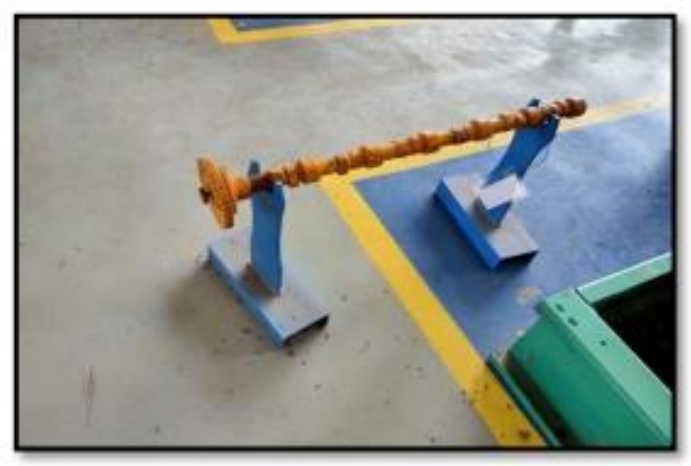

Gambar 6. Penempatan Part yang Salah

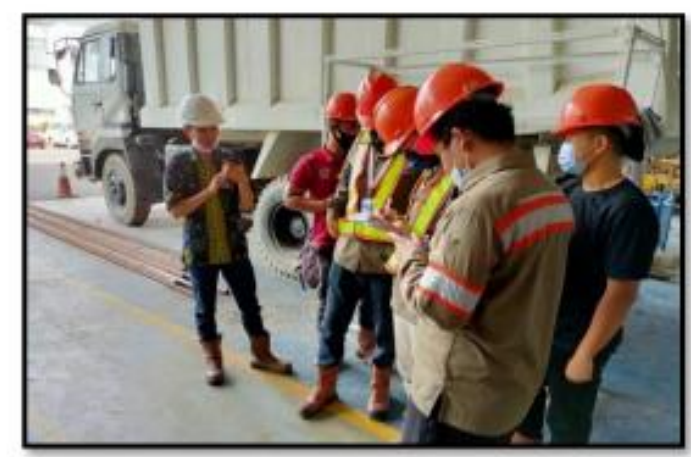

Gambar 3. Wawancara Instruktur

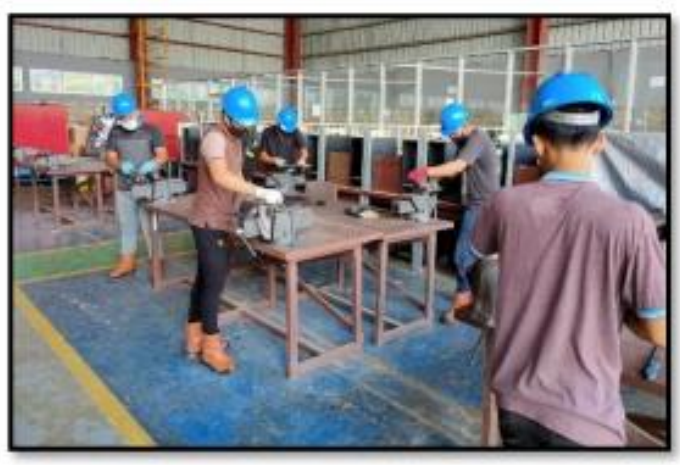

Gambar 5. Praktikum Pengikiran

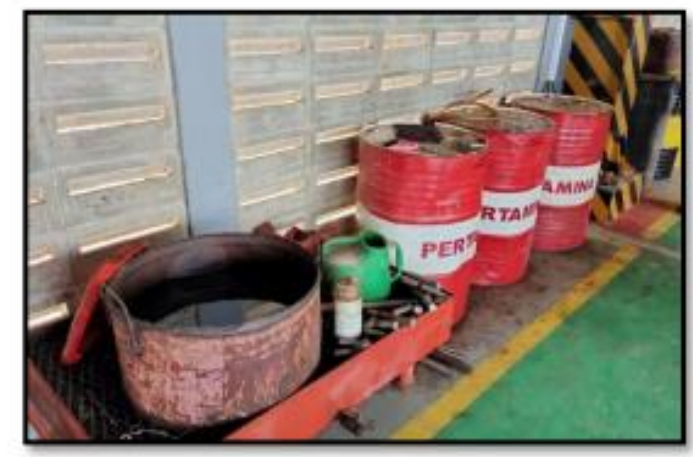

Gambar 7. Penempatan Oli Tidak pada Area B3

Gambar 2. Dokumentasi 